\title{
Quality of meat of steers of different breeds reared for eco-tourism in Heavy metal toxicity prone region
}

\author{
Z.T. Baeva1, V.V. Tedtova ${ }^{1}$, A.S. Dzhaboeva ${ }^{2}$, V.R. Kairov ${ }^{3,4}$, M.G. \\ Kokaeva $^{1}$, Z.Yu. Kaloeva ${ }^{5}$, A.A. Stolbovskaya ${ }^{1}$
}

\begin{abstract}
${ }^{1}$ North-Caucasian Mining and Metallurgical Institute (State Technological University), Vladikavkaz 362021; ${ }^{2}$ Kabardino-Balkarian State Agrarian University named after V.M. Kokova, 360030, Kabardino-Balkarian Republic, Nalchik, Lenin Ave., 1v.; ${ }^{3}$ Gorsky State Agrarian University, 362040, Vladikavkaz, 37 Kirov Street; ${ }^{4}$ North Caucasian Research Institute of Mountain and Piedmont Agriculture - the Affiliate of Vladikavkaz Scientific Centre of the Russian Academy of Science, 363110, 1 Williams Str., Mihkailovskoe vil., Republic of North Ossetia Alania; ${ }^{5}$ North-Ossetian State University named after K.L. Khetagurov, Vladikavkaz, 362025.

*Corresponding author e-mail: E-mail: zarina_kt@mail.ru
\end{abstract}

Journal of Livestock Science (ISSN online 2277-6214) 12: 356-361

Received on 5/11/21; Accepted on 5/12/21; Published on 25/12/21

doi. 10.33259/JLivestSci.2021.356-361

\begin{abstract}
The aim of the study was to control the consumer qualities of meat of steer of different breeds and meat products when grown on a diet with excessive levels of heavy metals when organizing ecological tourism in the Republic of North Ossetia - Alania. The study was conducted on the animals of different breeds (10 goals each): group I (control) - Red Steppe (dairy breed), group II (experimental 1) - Black Pied (dairy breed), and group III (experimental 2) - Schwyz (beef and dairy breed). In the case of an increased content of heavy metals in feed in the ecological tourism zone of the Republic of North Ossetia - Alania (Russia), it is advisable to breed Swiss calves, which are distinguished by higher rates of muscle growth and, as a result, increased ecological, nutritional and biological value of meat. Calves of the 2nd experimental group (Schwyz) had better parameters of hot carcass weight, visceral fat content and cutting weight than their control group. The higher proportion of meat of the first and first grade in the carcasses of animals of the 2 experimental groups is the result of an increase in growth rates with an increased content of heavy metals in feed. We observed a decrease in zinc levels by $77.3 \%$, lead by $81.0 \%$ and cadmium by $88.2 \%$ in meat samples from experimental group 2 calves. The content of elements in the samples of musculus longissimus from the calves of the III experimental group did not exceed the MPC. The third sample of the final meat product from Schwyz animals contained $1.24 \%$ and $1.49 \%$ more dry matter and protein than the control sample. The third sample of «Slavyanskii baked and smoked» meat product contained 79.8\% less zinc, $88.9 \%$ less lead and $83.32 \%$ less cadmium than the control sample. The content of heavy metals in the third sample obtained from the meat of Schwyz calves was below the MPC, and this sample showed the best results for organoleptic evaluation.
\end{abstract}

Keywords: Steer; Heavy metals; Physical and chemical properties; Meat; Meat products; Organoleptic characteristics. 


\section{Introduction}

Provision of the population of Russia with safe and high-quality meat has recently become a priority. This issue is particularly pressing in the regions that have been exposed to substantial industrial impact. It is well known that chemical and biological pollutants have significant influence on the cattle productivity, physical, chemical, and technological qualities of the meat products, and on the metabolism of young cattle. Among numerous pollutants, heavy metals hold a special place (Dubrovin et al., 2012; Temiraev et al., 2008; Baeva et al., 2013).

The biological impact of heavy metals is related to their high toxicity and their ability to accumulate in the organism, causing polytropic negative effects. The accumulation of heavy metals occurs, even if their levels in the natural environment are substantially lower than maximum permissible concentrations (MPC). These elements get to the organisms of the animals through the trophic chains, and their deposits negatively affect the quality of products (Osikina et al., 2012; Baeva et al., 2011; Chabaev et al., 2018).

The Republic of North Ossetia - Alania (RNO - Alania) is one of the regions with the highest levels of heavy metal pollution in Russia due to a large number of the non-ferrous industrial plants in Vladikavkaz. The results of the studies show that the major soil pollutants in the Republic are acid-soluble metals: lead, zinc, cadmium, and copper. The highest levels of the former three elements have been detected in Vladikavkaz and within the 15-km range from the center of the Republic (Tedtova et al., 2013; Temiraev et al., 2012; Baeva et al., 2011).

A comparative assessment of the quality of the meat of fattened young cattle of different breeds with contamination of feed with heavy metals in the conditions of the North Caucasus was carried out for the first time.

The aim of the study was to control the consumer qualities of meat of steer of different breeds and meat products when grown on a diet with excessive levels of heavy metals when organizing ecological tourism in the Republic of North Ossetia - Alania.

\section{Material and methods}

To achieve our goal, we conducted a scientific and production experiment on the premises of (JSC)

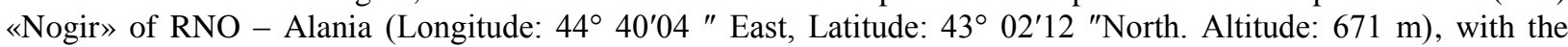
experimental design shown in Table 1.

The study was conducted on the animals of different breeds: group I (control) - Red Steppe (dairy breed), group II (1) - Black Pied (dairy breed), and group III (2) - Schwyz (beef and dairy breed), that are well recognized in the region. According to the experimental design, we selected 3 groups, each containing 10 animals, with matching age, sex, and live weight. The animals of the examined groups were raised on the diets with increased concentrations of zinc, lead, and cadmium (Table 2).

According to the chemical analysis results, it was found that the diets of the test animals exceeded the maximum permissible concentration for zinc: at the age of 6-9 months - 2.01 times; 9-12 months - 2.14 times; 12 15 months -2.17 times and 15-18 months -2.21 times. During these age periods, the diets of the test steers were found to contain lead in the amount of $160.5 ; 180.1 ; 196.9$ and $204.1 \mathrm{mg}$ and cadmium $-10.31 ; 10.42 ; 11.04$ and $12.20 \mathrm{mg}$, respectively. Heavy metal uptake from the forage by the organisms of the animals of the examined breeds was virtually identical.

The study was conducted in two steps. At the first step, we examined the slaughter and meat qualities, physical, chemical, and technological properties of raw meat, according to the guidelines by Osikina (Osikina et al., 2013), on the premises of JSC «Nogir» of RNO - Alania.

At the second step, we examined the samples of musculus longissimus, collected from the carcasses of the calves of Red Steppe ( $1^{\text {st }}$ sample), Black Pied ( $2^{\text {nd }}$ sample), and Schwyz ( ${ }^{\text {rd }}$ sample) breeds. The samples of «Slavyanskii baked and smoked» (in the conditions of the meat-processing enterprise "Dubois", the city of Vladikavkaz, North Ossetia - Alania) sirloin were produced from this meat, according to the technology, shown in Fig. 1.

We further performed standard examination of the physical, chemical, and organoleptic properties of the studied sirloin samples, produced from the meat of the animals of different breeds. Heavy metal concentrations in the meat samples were measured with the AAZ-115-M1 spectrophotometer. The experimental data were statistically analyzed with the Excel computer software from the current Microsoft Office package.

\section{Results and discussion}

The results of the slaughtering of the calves from the studied groups at the age of 18 months allowed us to evaluate their slaughter qualities (Table 3). After 24-hour fasting, the calves of groups 1 and 2 had significantly $(\mathrm{P}<0.05)$ higher pre-slaughter weight, exceeding the values in the calves of group I (control) by $4.1 \%$ and $5.7 \%$, respectively. We showed that the calves of group 2 had significantly $(\mathrm{P}<0.05)$ higher values of the hot carcass weight (by $8.8 \%$ ), visceral fat weight (by $10.9 \%$ ), and dressed weight (by $8.9 \%$ ), than their matched controls.

$1.6 \%$ increase in the dressing yield in the animals of group 2, as compared to group Control, was also statistically significant $(\mathrm{P}<0,05)$. The animals of group Experimental 2 also had $4.2 \%$ and $7.1 \%$ larger weight of neck and forelegs, respectively, than their matched controls, but the relative weight to the total cooled carcass weight was lower than in the control group. The assessment of the carcass fatness allowed classifying the calves of the experimental groups as first grade. 
Table 1 - Design of the scientific and production experiment

\begin{tabular}{|l|c|c|c|}
\hline \multicolumn{1}{|c|}{ Groups } & No of animals & Animal breed & Feeding features \\
\hline Control & 10 & Red Steppe & $\begin{array}{c}\text { Basic diet (BD) with higher conc. } \\
\text { of } \mathrm{Zn}, \mathrm{Pb} \text { and Cd }\end{array}$ \\
\hline Group 1 & 10 & Black Pied & BD \\
\hline Group 2 & 10 & Schwyz & BD \\
\hline
\end{tabular}

Table 2 - Daily diet for steers aged 9-12 months

\begin{tabular}{|l|c|c|}
\hline \multicolumn{1}{|c|}{ Indicator } & Required rate & Indeed contains \\
\hline Feed (kg) and additives: & & 2 \\
\hline Sudan grass hay & - & 10 \\
\hline Corn silage + sorghum & - & 0.9 \\
\hline Dry pulp & - & 2.85 \\
\hline Mixed feed & - & 0.8 \\
\hline Feed molasses & - & 28 \\
\hline Table salt, g & 35 & \\
\hline The diet contains: & & 69.8 \\
\hline Dry matter, kg & 70.0 & 53.30 \\
\hline Exchange energy, MJ & 53.0 & 1200 \\
\hline Crude protein, g & 1175 & 778.7 \\
\hline Digestible protein, g & 765 & 2008 \\
\hline Crude fiber, g & 1990 & 1202 \\
\hline Starch, g & 1215 & 806 \\
\hline Sugar, g & 810 & 298 \\
\hline Crude fat, g & 310 & 56.1 \\
\hline Calcium, g & 54 & 30 \\
\hline Phosphorus, g & 29 & 26.5 \\
\hline Sulfur, g & 27 & 1804 \\
\hline Iron, mg & 600 & 85.48 \\
\hline Copper, mg & 850 & 264 \\
\hline Zinc, mg & - & \\
\hline Lead, mg & & \\
\hline Cadmium, mg & - & \\
\hline & & \\
\hline & & \\
\hline
\end{tabular}

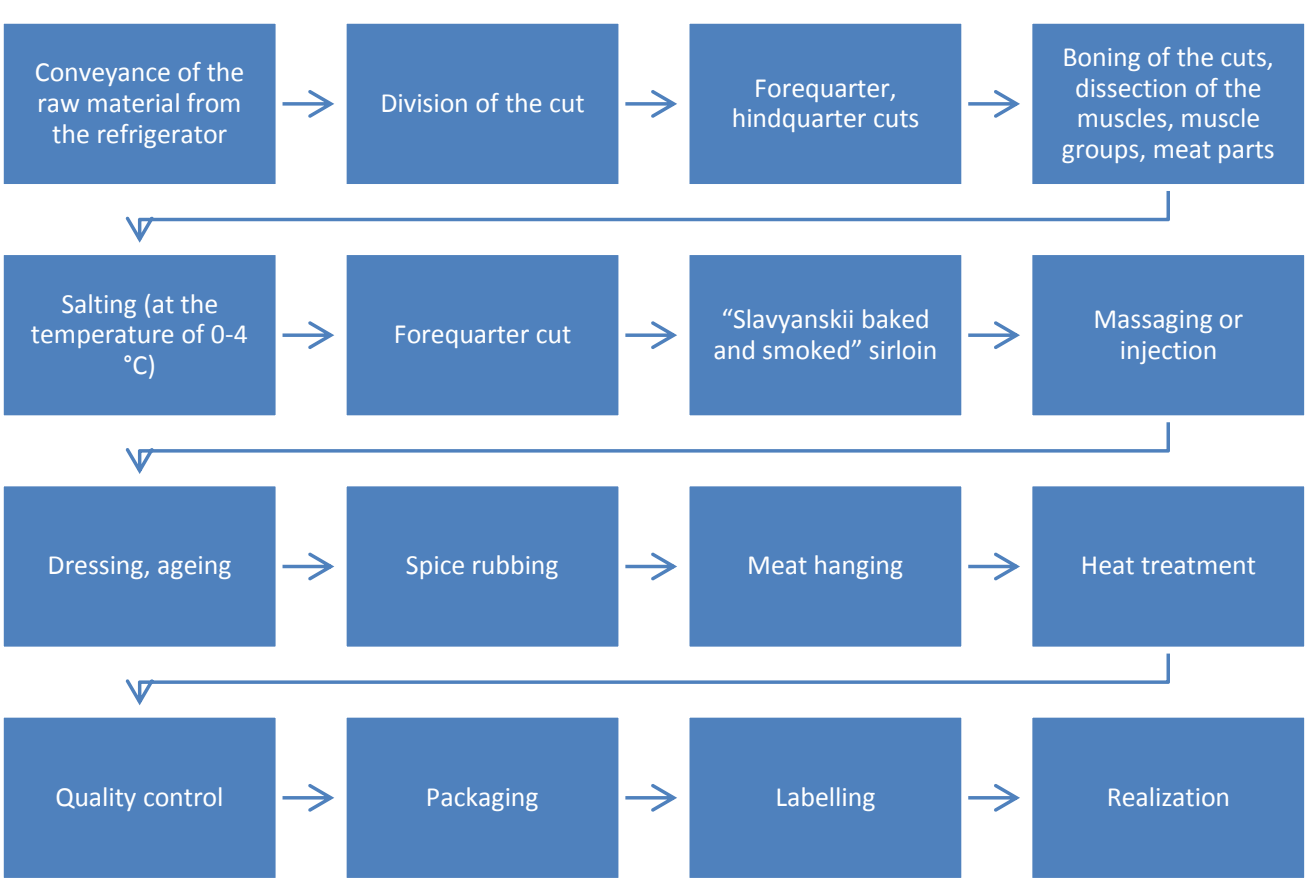

Fig. 1 - Technological procedure for the production of the «Slavyanskii baked and smoked» sirloin samples from beef. 
One of the important qualities of the meat productivity of the fattened calves is morphological composition of the carcasses. Table 4 shows the changes in morphological composition of the carcasses of the animals of the studied groups, caused by heavy metals, present in their diet. The carcasses of the fattened calves of the experimental groups 1 and 2 had a large proportion of muscles. As a result, the meat weight in these groups was significantly $(\mathrm{P}<0.05)$ higher than in group Control, by $6.6 \%$ and $10.3 \%$, respectively. We also observed negative biological correlation between the relative weight of meat and bones, with respect to the total weight of the cooled carcass. Due to this correlation, the meatiness index, reflecting the grade of the carcass, was higher in the calves of the experimental groups 1 and 2 by 0.17 and 0.30 units, as compared to the carcasses from the control group.

Due to improvement of the ratio between the carcass meat and bones, the yield of the edible parts had increased in the animals of groups 1 and 2. Moreover, the carcasses of the calves of the experimental group III had the highest ratio of the edible to non-edible parts, which exceeded the values for group control by $6.2 \%$.

We conducted an experiment on boning the carcasses of the animals of the studied groups to examine the distribution of the quality grades (Table 5). The absolute yield of the prime grade and first grade meat was observed in the calves of the group 2, exceeding the values for their matched controls by 3.2 and $7.9 \mathrm{~kg}$, respectively; the difference was statistically significant $(\mathrm{P}<0.05)$ in both cases. Moreover, $61.7 \%$ of meat of the animals of the group 2 was classified as prime and first grade, which is $1.0 \%$ more than in the control group. The carcasses of the calves of the group 2 had an intermediate meat grade distribution between the animals of the control group and the group 2 .

We suppose that an increased proportion of prime grade and first grade meat in the carcasses of the animals of the groups 1 and 2 is a result of enhanced growth rates, caused by higher levels of heavy metals in the forage. The nutritional value of meat depends on the content of protein and fat, as well as on the general energy value. The best quality and availability of the nutrients in meat can be achieved, if the dry matter of meat contains approximately equal amounts of protein and fat. The muscle tissue is the major constituent of the carcass, and its growth rates define the meat productivity of the animals.

It is well known that calves maintain the ability for efficient protein assimilation and extensive development of the muscle tissue for eighteen months, although it gradually declines. Given this, we examined the chemical composition of musculus longissimus of the studied animals (Table 6). We observed positive effects of the breed qualities on the chemical composition of meat in the animals of the experimental group 2 during the most extensive proliferation of the muscle tissue in the fattened calves. They resulted in the highest increase in the proportion of the dry matter (by $1.50 \%, \mathrm{P}<0.05$ ) and protein (by $0.92 \%, \mathrm{P}<0.05$ ) in the meat samples of the calves of group Experimental 2, as compared to their matched controls.

The results of the chemical analysis of musculus longissimus revealed significant $(\mathrm{P}<0.05)$ decrease in the levels of zinc (by $77.3 \%$ ), lead (by $81.0 \%$ ), and cadmium (by $88.2 \%$ ) in the meat samples from the calves of the experimental group 2, as compared to the animals of the control group. Moreover, the concentrations of all elements in the samples of musculus longissimus from the calves of the experimental group 2 did not exceed the relevant MPCs. The research results showed that animals of the Swiss breed have higher slaughter and meat qualities than bulls of the black-and-white and red steppe breed (Osikina et al., 2012; Chabaev et al., 2018).

Table 3 - Slaughter parameters of the calves $(n=3)$

\begin{tabular}{|l|c|c|c|}
\hline \multirow{2}{*}{\multicolumn{1}{|c|}{ Parameters }} & \multicolumn{3}{c|}{ Group } \\
\cline { 2 - 4 } & Control & 1 & 2 \\
\hline Pre-slaughter weight, $\mathrm{kg}$ & $393.0 \pm 3.15$ & $409.2+3.41$ & $415.4 \pm 2.96$ \\
\hline Hot carcass weight, $\mathrm{kg}$ & $194.3 \pm 1.77$ & $205.8+1.82$ & $211.4+1.95$ \\
\hline Visceral fat weight, $\mathrm{kg}$ & $10.1+0.12$ & $10.9+0.17$ & $11.2+0.14$ \\
\hline Dressed weight, $\mathrm{kg}$ & $204.4 \pm 1.97$ & $216.7+2.03$ & $222.6 \pm 1.76$ \\
\hline Dressing yield, $\%$ & $52.0 \pm 0.20$ & $53.0+0.35$ & $53.6 \pm 0.22$ \\
\hline
\end{tabular}

Table 4 - Morphological composition of the carcasses $(n=3)$

\begin{tabular}{|l|l|l|l|}
\hline \multirow{2}{*}{\multicolumn{1}{|c|}{ Parameters }} & \multicolumn{3}{c|}{ Group } \\
\cline { 2 - 4 } & \multicolumn{1}{|c|}{ Control (\%) } & \multicolumn{1}{c|}{$1(\%)$} & \multicolumn{1}{c|}{$2(\%)$} \\
\hline Weight of the cooled carcass, $\mathrm{kg}$ & $192.1+1.9(100)$ & $203.5+1.5(100)$ & $209.2+1.7(100)$ \\
\hline Meat, $\mathrm{kg}$ & $149.6+1.6(77.9)$ & $159.5+1.2(78.2)$ & $165.1+1.5(78.9)$ \\
\hline Bones, $\mathrm{kg}$ & $36.1+0.5(18.8)$ & $37.0+0.8(18.2)$ & $37.2+0.7(17.8)$ \\
\hline Cartilage and tendons, $\mathrm{kg}$ & $6.4+0.11(3.3)$ & $7.4+0.18(3.4)$ & $6.9+0.14(3.3)$ \\
\hline Meatiness index & 4.14 & 4.31 & 4.44 \\
\hline Ratio of the edible to the non-edible parts & 3.52 & 3.59 & 3.74 \\
\hline
\end{tabular}

Table 5 - Distribution of the meat grades in the calves of the studied groups $(n=3)$

\begin{tabular}{|l|l|c|c|}
\hline \multirow{2}{*}{\multicolumn{1}{|c|}{ Parameters }} & \multicolumn{3}{|c|}{ Group } \\
\cline { 2 - 4 } & \multicolumn{1}{|c|}{ Control } & $1(\%)$ & $2(\%)$ \\
\hline Meat weight, $\mathrm{kg}$ & $149.6+1.6(100)$ & $159.5+1.2(100)$ & $165.1+1.5(100)$ \\
\hline Prime grade, $\mathrm{kg}$ & $18.1+0.26(12.1)$ & $19.8+0.32(12.4)$ & $21.3+0.35(12.9)$ \\
\hline First grade, $\mathrm{kg}$ & $72.7+0.50(48.6)$ & $77.9+0.48(48.8)$ & $80.6+0.57(48.8)$ \\
\hline Second grade, $\mathrm{kg}$ & $58.8+0.39(39.3)$ & $61.8+0.38(38.8)$ & $63.2+0.44(38.3)$ \\
\hline
\end{tabular}


We were also interested in assessing the biological value of the meat samples (musculus longissumus) from the fattened calves of the studied groups through calculating the protein quality index (PQI) of meat, which equals to the ratio of the essential amino acid tryptophan to oxyproline (Table 7). We observed a significantly $(\mathrm{P}<0.05)$ higher content of tryptophan in the samples of musculus longissimus from the calves of the groups 1 and 2 , than in the samples from the animals of the control group I (by $3.7 \%$ and $6.3 \%$, respectively). There were no significant $(\mathrm{P}>0.05)$ differences in the content of oxyproline, a constituent of collagen fibers, in the samples of musculus longissimus from the animals of the studied groups. The meat samples from the calves of the experimental group 2 had the highest biological value, assessed through the protein quality index (PQI) calculated as the ratio of tryptophan to oxyproline. The animals of this group had significantly higher values of this parameter (by $10.5 \%$, $\mathrm{P}<0.05)$, measured for the samples of musculus longissimus, than the calves of group control.

Therefore, the meat samples from the Schwyz calves had the highest biological value of proteins, considering the increased growth rates of the muscles. The meat quality is determined by the proportions of the constituent tissues and their physical, chemical, and morphological properties that depend on the breed, age, and sex of the animal, breeding and fattening conditions, anatomical features of the cut. Heavy metals, inhibiting the myoglobin synthesis, may have dramatic impact on the development and energy value of the muscle tissue. Table 8 summarizes the results of the assessment of certain physical properties and energy value of musculus longissimus of the calves of the studied groups.

The concentration of hydrogen ions $(\mathrm{pH})$ is one of the major indicators of the meat quality. It has influence on the process of meat ageing and its preservation. Our studies showed that the activity of the medium samples, obtained from muscle longissimus of the calves of the studied groups, did not change in response to heavy metals and was compliant with the requirements for the meat samples with no defects.

Water-binding capacity and cooking shrinkage (loss of fluid during the heat treatment) of meat are very important for its technological properties. Meat juiciness depends on its water-binding capacity and content of intramuscular fat. Beef that contains a lot of bound water loses less fluid during the heat treatment. Therefore, we studied the water-binding capacity of the meat samples and observed the highest value of this parameter in the samples of musculus longissimus from the calves of the experimental group 2, which was $2.0 \%$ higher $(\mathrm{P}<0.05)$ than in their matched controls. As a result, the samples of musculus longissimus from the animals of the experimental group 2 were juicier and more tender, as their cutting load was $0.30 \mathrm{~kg} / \mathrm{cm}^{2}$ lower $(\mathrm{P}<0.05)$, and the muscle fiber diameter -5.3 microns larger $(\mathrm{P}<0.05)$ than in their matched controls.

The energy value of meat, as expected, was positively correlated with the fat content in the carcass meat. Therefore, the highest energy value was observed in the samples of musculus longissimus from the animals of the experimental group 2 that contained $0.30 \mathrm{MJ}$ more energy in $1 \mathrm{~kg}$ of meat than the control samples.

In the conditions of the Republic of North Ossetia-Alania, ecological tourists have great respect for the dishes «Slavyanskii baked and smoked». The technological processing of raw meat largely contributes to the chemical composition and nutritional value of the baked and smoked meat products. In view of this, we examined the chemical composition of the «Slavyanskii baked and smoked» sirloin samples, produced from meat of the studied animals. The third meat product sample from the Schwyz animals had significantly $(\mathrm{P}<0.05)$ higher content of dry matter (by 1.24\%) and protein (by 1.49\%), than the control sample. Our results are consistent with research data of a number of researchers (Tedtova et al., 2013; Temiraev et al., 2012).

We also observed lower levels of heavy metals in the meat product samples than in the raw meat. The best ecological and nutritional qualities were found in the «Slavyanskii baked and smoked» sirloin samples, produced from the meat of the Schwyz calves, therefore, the third sample had significantly $(\mathrm{P}<0.05)$ lower levels of zinc (by $79.8 \%$ ), lead (by 88.9\%), and cadmium (by 83.32\%), than the control sample. Moreover, the content of heavy metals in the third sample of the «Slavyanskii baked and smoked» sirloin, produced from the meat of the Schwyz calves, did not exceed the relevant MPC.

We also performed the tasting assessment of three samples of the «Slavyanskii baked and smoked» sirloin, produced from the meat of the calves of the studied groups, and evaluated their quality, using a 9-score scale. The results of the tasting assessment of the compared meat product (sirloin) samples, produced from musculus longissimus of the calves of different breeds showed that the third sample had the highest organoleptic quality score, significantly $(\mathrm{P}<0.05)$ outnumbering the first (control) sample by the following criteria: appearance - by 0.38 points, cutting colour - by 0.32 points, taste - by 0.27 points, and total score - by 0.21 points.

Table 6 - Chemical composition of the meat samples (musculus longissimus) from the calves $\%(n=3)$

\begin{tabular}{|l|c|c|c|}
\hline \multirow{2}{*}{ Parameters } & \multicolumn{2}{c|}{ Group } & 2 \\
\cline { 2 - 4 } & Control & 1 & $75.30 \pm 0.49$ \\
\hline Water & $76.80 \pm 0.39$ & $75.82 \pm 0.56$ & $24.70 \pm 0.53$ \\
\hline Dry matter & $23.20 \pm 0.23$ & $24.18 \pm 0.51$ & $20.05 \pm 0.23$ \\
\hline Protein & $19.13 \pm 0.24$ & $19.76 \pm 0.18$ & $3.03 \pm 0.19$ \\
\hline Fat & $2.85 \pm 0.11$ & $2.98 \pm 0.12$ & $1.62 \pm 0.12$ \\
\hline Ash & $1.22 \pm 0.18$ & $1.44 \pm 0.08$ & $1: 0.15$ \\
\hline Protein / fat & $1: 0.15$ & $1: 0.15$ & $22.6 \pm 0.12$ \\
\hline Zinc $(\mathrm{MPL}=70 \mathrm{mg} / \mathrm{kg})$ & $99.6 \pm 0.13$ & $47.8 \pm 0.26$ & $0.010 \pm 0.001$ \\
\hline Cadmium $(\mathrm{MPL}=0.05 \mathrm{mg} / \mathrm{kg})$ & $0.092 \pm 0.001$ & $0.058 \pm 0.001$ & $0.16 \pm 0.002$ \\
\hline Lead $(\mathrm{MPL}=0.5 \mathrm{mg} / \mathrm{kg})$ & $0.85 \pm 0.003$ & $0.56 \pm 0.001$ & \\
\hline
\end{tabular}


Table 7 - Biological value of the meat samples (musculus longissimus) from the calves $(\mathrm{n}=3)$

\begin{tabular}{|l|c|c|c|}
\hline \multirow{2}{*}{\multicolumn{1}{|c|}{ Parameters }} & \multicolumn{3}{|c|}{ Group } \\
\cline { 2 - 4 } & Control & 1 & 2 \\
\hline Tryptophan, mg\% & $348 \pm 3.8$ & $361 \pm 2.9$ & $370 \pm 3.3$ \\
\hline Oxyproline, mg\% & $78 \pm 3.6$ & $76 \pm 2.5$ & $75 \pm 2.8$ \\
\hline PQI & $4.46 \pm 0.05$ & $4.75 \pm 0.04$ & $4.93 \pm 0.05$ \\
\hline
\end{tabular}

Table 8 - Physical properties and energy value of the meat samples from the calves $(n=3)$

\begin{tabular}{|l|c|c|c|}
\hline \multirow{2}{*}{\multicolumn{1}{|c|}{ Parameters }} & \multicolumn{3}{c|}{ Group } \\
\cline { 2 - 4 } & Control & 1 & 2 \\
\hline $\mathrm{pH}$ (medium activity) & $5.72 \pm 0.02$ & $5.75 \pm 0.01$ & $5.76 \pm 0.02$ \\
\hline Water-binding capacity, \% & $58.0 \pm 0.38$ & $59.6 \pm 0.26$ & $60.0 \pm 0.35$ \\
\hline Cutting load, kg/cm ${ }^{2}$ & $2.40 \pm 0.07$ & $2.29 \pm 0.06$ & $2.10 \pm 0.04$ \\
\hline Muscle fiber diameter, microns & $38.7 \pm 0.29$ & $41.4 \pm 0.37$ & $44.0 \pm 0.48$ \\
\hline Energy value of 1 kg of meat, MJ & 5.20 & 5.35 & 5.50 \\
\hline
\end{tabular}

A comparative assessment of the quality of the meat of fattened young cattle of different breeds with contamination of feed with heavy metals in the conditions of the North Caucasus was carried out for the first time.

The results obtained during the experiment showed that animals of the Swiss breed had a higher meat productivity, consumer qualities and environmental safety of meat. This is explained by the better adaptation of animals of this breed to the excess content of heavy metals in feed and to local climatic conditions. In addition, in Swiss gobies, these toxins accumulate to a greater extent in the bones, and not in the meat.

Conclusion To improve the consumer qualities and sanitary and hygienic properties of meat dishes for participants in ecological tourism in the Republic of North Ossetia - Alania (where there is an increased content of heavy metals in feed), we recommend producing meat from Swiss steer.

\section{References}

1) Baeva, Z.T., E.S. Dzodzieva and Z.Ya. Biboeva, 2011. Comparative assessment of the meat productivity of the bulls of different breeds in the context of RNO - Alania. Sustainable Development. of Mountain Territories, 4(10): 89-91.

2) Baeva, Z.T., E.S. Dzodzieva, M.G. Kokaeva and Z.Ya. Tsopanova, 2011. Ecological and nutritional assessment of meat of the calves of different breeds. In: Proceedings of the $3^{\text {rd }}$ International Scientific and Practical Conference 'Science, Education and innovations for the agro-industrial complex: the state an perspectives'. P. 125-127. Maikop.

3) Baeva, Z.T., V.V. Tedtova, Z.Ya. Tsopanova and E.S. Dzodzieva, 2013. Comparative assessment of the accumulation of heavy metals in meat, organs, and tissues of the calves of different breeds. In: Proceedings of the International Scientific and Practical Conference 'Animal husbandry in Russia in accordance with the State agricultural Program for 2013-2020’. Pp. 132-135. Nizhnii Arkhyz, the Karachay-Cherkess Republic.

4) Chabaev, M.G., Tedtova, V.V., Baeva, Z.T., Kononenko, S.I., Tarchokov, T.T., Chopikashvili, L.V. 2018. Effect of different adsorbent doses on the morphological and biochemical composition of blood of bull calvesin detoxification of heavy metals. Journal of Pharmaceutical Sciences and Research. 10(5): 1122-1124.

5) Dzodzieva, E.S., Dzodzieva, E.S., Kokaeva, M.G., Temiraev, R.B., Abramova, G.A., D.O. Gurtsieva 2015. Comparative Assessment of the Quality of Meat of Gobies Fattened in the Technogenic Zone. Meat Industry 2: $46-48$.

6) Dubrovin, A.I., Baeva, Z.T., Dzodzieva, E.S. and Tsopanova, Z.Ya. 2012. Ecological and nutritional assessment of meat from the calves of different breeds, fed with the rations with excessive content of heavy metals. Zootechnics, 4: 14-16.

7) Osikina, R.V., Baeva, Z.T., Dzodzieva, E.S., Tsopanova, Z.Ya. 2012. Assessment of the meat qualities of gobies of different breeds fed in the technogenic zone of North Ossetia - Alania. Bulletin of the Mountain State Agrarian University. - Vladikavkaz. 49(1-2): 95-98.

8) Temiraev, R.B., Kairov, V.R., Khamitsaeva, E.S., Tuaeva, T.K. 2008. Heavy metal contamination: how to keep pork safe. Compound feed 4: 34-35.

9) Temiraev, R.B., Kokaeva, F.F., Tedtova, V.V., Baeva, A.A., Khadikova, M.A., Abaev, A.V. 2012. A method of increasing the dietary qualities of meat and improving metabolism in broiler chickens in the technogenic zone of the Republic of North Ossetia-Alania [Text]. News of the Mountain State Agrarian University. Vladikavkaz. 49(4): 130-133. 